\title{
Monoclonal antibody ONS-M21 recognizes integrin $\alpha 3$ in gliomas and medulloblastomas
}

\author{
H Kishima', K Shimizu', K Tamura', Y Miyao', E Mabuchi', E Tominaga², J Matsuzaki² and T Hayakawa ${ }^{1}$ \\ 'Department of Neurosurgery, Osaka University Medical School, 2-2 Yamadaoka, Suita, Osaka 565-0871, Japan, and 'Exploratory Research Laboratory Chugai \\ Pharmaceutical Co. Ltd, 1-135 Komakado, Gotenba, Shizuoka 412-8153, Japan
}

Summary The monoclonal antibody ONS-M21 recognizes an antigen found on the surface of glioma and medulloblastoma cells but does not react with the antigens of normal brain tissue. We purified and identified the 140-kDa protein by means of an antibody-binding affinity column. This 140-kDa antigen has sequences homologous to the amino-terminal region and five parts of the internal domain of integrin $\alpha 3$. When the integrin $\alpha 3$-related sequences was amplified and used to analyse the mRNA of glioma and medulloblastoma surgical specimens, the transcription level of integrin $\alpha 3$ mRNA appeared to be quantitatively correlated with the grade of malignancy. These findings suggest that the ONS-M21 antibody, which reacts with integrin $\alpha 3$, might be useful in the diagnosis of gliomas and medulloblastomas.

Keywords: glioma; medulloblastoma; monoclonal antibody; integrin $\alpha 3$

Medulloblastomas are the most common type of primitive neuroectodermal tumours observed in the central nervous system of children. In spite of recent advances in therapy, including microsurgery, combined chemotherapy and radiotherapy, the longterm prognosis for patients with these tumours is not satisfactory (Evans et al, 1990), pointing to a need for more specific and efficient therapies. Antibodies that recognize medulloblastoma cells are expected to act as diagnostic and therapeutic reagents. Therefore, we attempted to produce a medulloblastoma-specific monoclonal antibody (MAb). Immunization of mice with ONS-76 medulloblastoma cells (Tamura et al, 1989) successfully produced the antibodies referred to as ONS-M21 MAb (Moriuchi et al, 1993). ONS-M21 MAb reacted with a surface antigen of most glioma and medulloblastoma cell lines, and it also reacted with surgical specimens of gliomas and medulloblastomas. On the other hand, this MAb did not show cross-reactivity with peripheral blood cells or normal brain tissue. However, mouse antibodies are highly immunogenic in humans, and, hence, their clinical use may be limited. We genetically engineered a recombinant, humanized version of ONS-M21 MAb (hONS-M21 Ab) by means of CDR grafting (Ohtomo et al, 1995) in order to eliminate immunogenicity. This humanized Ab competed with ONS-M21 MAb for binding to glioma cells. In addition, this $\mathrm{Ab}$, when labelled with an isotope, was capable of depicting tumour location by an autoradiographic technique. Thus, humanized $\mathrm{Ab}$ possesses various advantages that make it attractive for clinical applications.

As the target molecule of ONS-M21 remains unknown, identification of this antigen is a necessary step before any clinical use of this antibody can be attempted. In the present study, we purified ONS-M21 antigen from ONS-76 cell lysates by means of an Abbinding affinity column, analysed the amino acid sequences of the ONS-M21 binding protein and identified the target molecule of

Received 24 September 1997

Revised 29 April 1998

Accepted 30 April 1998

Correspondence to: $\mathrm{K}$ Shimizu
ONS-M21 MAb. In addition, the mRNA level of this antigen was analysed by reverse transcription-polymerase chain reaction (RTPCR) in surgical specimens of gliomas and medulloblastomas.

\section{MATERIALS AND METHODS}

\section{Cell culture conditions and preparation of the monoclonal antibody}

The human medulloblastoma cell line ONS-76 was established in our laboratory (Tamura et al, 1989; Institution for fermentation, Osaka, No. 50355), maintained in Dulbecco's modified Eagle medium (DMEM) with 10\% heat-inactivated fetal bovine serum (FBS) and $50 \mu \mathrm{g} \mathrm{ml}^{-1}$ gentamycin, and incubated in a humidified $10 \%$ carbon dioxide-in-air atmosphere at $37^{\circ} \mathrm{C}$. ONS-76 cells were collected using a cell scraper and washed with cold Trisbuffered saline (TBS; $10 \mathrm{mmol} \mathrm{l}^{-1}$ Tris-Cl, $150 \mathrm{mmol} \mathrm{l}^{-1} \mathrm{NaCl}$, $\mathrm{pH}$ 8.0). The cells were resuspended in a detergent solution (TBS with $0.5 \%$ Tween-20 and $1 \mathrm{mg} \mathrm{ml} \mathrm{m}^{-1} p$-amidinophenyl methanesulphonyl fluoride hydrochloride) at a concentration of $10^{6}$ cells $\mathrm{ml}^{-1}$, and then shaken for $2 \mathrm{~h}$ at $4^{\circ} \mathrm{C}$ to elute the cell extract. After centrifuging (3000 r.p.m., $20 \mathrm{~min}$ ), the supernatant was collected as cell extract and stored at $-80^{\circ} \mathrm{C}$.

ONS-M21 MAb (IgG1) was purified as previously described (Moriuchi et al, 1993).

\section{IMMUNOPRECIPITATION}

To label ONS-76-producing proteins with [ $\left.{ }^{35} \mathrm{~S}\right]$ methionine, ONS76 cells were preincubated overnight in methionine-free MEM (ICN Biomedicals, Costa Mesa, CA, USA), and then cultured in methionine-free MEM with $10 \% \mathrm{FBS}$ and $100 \mu \mathrm{Ci} \mathrm{ml}^{-1}$ of an L$\left[{ }^{35} \mathrm{~S}\right]$ in vivo cell labelling mix (Amersham, Buckinghamshire, UK) for $5 \mathrm{~h}$ in a humidified $10 \%$ carbon dioxide-in-air atmosphere at $37^{\circ} \mathrm{C}$. The cell extract was then obtained as described above. This cell extract $(1 \mathrm{ml})$ was preincubated with $50 \mu$ l of protein A-Sepharose (Pharmacia, Uppsala, Sweden) conjugated with rabbit anti-mouse IgG1 (Cappel, Durham, NC, USA) for $1 \mathrm{~h}$ at 
$4^{\circ} \mathrm{C}$. After centrifuging, the supernatant was incubated at $4{ }^{\circ} \mathrm{C}$ with $80 \mu \mathrm{g}$ of ONS-M21 MAb for $1 \mathrm{~h}$ and then with $50 \mu \mathrm{l}$ of protein A-Sepharose conjugated with rabbit anti-mouse IgG1 for $1 \mathrm{~h}$ at $4^{\circ} \mathrm{C}$. In order to compare this antibody with another commercially available antibody (P1B5; Dakopatts, Glostrup, Denmark) that recognizes integrin $\alpha 3$, the cell extract was preimmunoprecipitated with P1B5 Ab instead of ONS-M21 MAb, centrifuged and the supernatant reimmunoprecipitated with ONS-M21 MAb. The final immunoprecipitate was washed five times with TBS and then boiled in sample buffer containing $62.5 \mathrm{~mm}$ Tris- $\mathrm{Cl}$ ( $\mathrm{pH}$ 6.8), 10\% glycerol, $2 \%$ sodium dodecyl sulphate (SDS), 2\% 2-mercaptoethanol and $0.1 \%$ bromophenol blue for $5 \mathrm{~min}$ to separate protein A-Sepharose and rabbit immunoglobulins. The precipitate was applied to a $6 \%$ SDS polyacrylamide gel electrophoresis (SDS-PAGE). The dried gel was autoradiographed by exposure to a BAS-IIIs imaging plate (Fuji Photo Film, Tokyo, Japan) for $12 \mathrm{~h}$ and analysed with BAS 1000 (Fuji Photo Film). The negative control was incubated with non-immune mouse IgG1 (Tago Company, Burlington, CA, USA) instead of ONS-M21.

\section{Purification of ONS-M21 antigen}

To obtain a sufficient amount of the antigen, $1.2 \times 10^{10}$ cells were lysed as described above. The cell extract was dialysed to decrease the Tween-20 concentration to $0.1 \%$. Cyanogen bromide $(\mathrm{CNBr})-$ activated Sepharose (Pharmacia) was coupled with $20 \mathrm{mg}$ of ONS-M21 monoclonal antibody and the coupled gel was embedded into a column $(0.8 \times 5 \mathrm{~cm})$ and kept at $4^{\circ} \mathrm{C}$. The cell extract was applied to the column at a rate of $5-10 \mathrm{ml} \mathrm{h}^{-1}$. After washing the column with $1000 \mathrm{ml}$ of TBS containing $0.1 \%$ Tween-20, bound proteins were eluted in 500- $\mu$ l fractions with $0.05 \mathrm{M}$ glycine, $0.1 \%$ Tween- 20 and $0.5 \mathrm{M}$ sodium chloride $(\mathrm{pH}$ 2.5 ) at a flow rate of $8 \mathrm{ml} \mathrm{h}^{-1}$, and then immediately neutralized with $1 \mathrm{M}$ Tris- $\mathrm{Cl}$ ( $\mathrm{pH} \mathrm{8.0)}$ ). To estimate the concentration of the target protein, $10 \mu \mathrm{l}$ of each fraction was blotted onto a nitrocellulose membrane and analysed by dot-blot enzyme-linked immunosorbent assay (ELISA) using $30 \mu \mathrm{g} \mathrm{ml}^{-1}$ ONS-M21 as the primary antibody and 1:500 of peroxidase-conjugated goat antimouse IgG (Zymed, San Francisco, CA, USA) as the secondary antibody. Immunocomplexes were revealed using the ECL system (Amersham) and the absorbency was measured using the Image Quant program (Molecular Dynamics, Sunnyvale, CA, USA). Positive fractions were mixed together, dialysed in TBS containing $0.1 \%$ Tween-20, and reapplied to the affinity column. The bound protein was eluted and analysed as described above. Positive fractions were used for amino acid sequence analysis.

\section{Analysis of the amino acid sequence of the ONS-M21 antigen}

The eluted sample was condensed 30-fold using a Centricon 50 concentrator (Amicon, Beverly, MA, USA). To analyse the aminoterminal amino acid sequence, $10 \%$ of the sample was separated by SDS-PAGE and electroblotted ( $\left.1 \mathrm{~mA} \mathrm{~cm}^{-2}, 90 \mathrm{~min}\right)$ onto a PVDF membrane (Bio-Rad, Hercules, CA, USA). The membrane was stained with $0.1 \%$ Ponceau $\mathrm{S}$ and $2 \%$ acetic acid. The main band $(140 \mathrm{kDa})$ was cut out and the N-terminal amino acid sequence of the isolated peptide was analysed on a protein sequencer (476A Protein Sequencer, Applied Biosystems). To digest the protein at methionine residues, the isolated band was dissolved in $70 \%$ formic acid containing $2 \mathrm{mg}$ of $\mathrm{CNBr}$ and then incubated for $18 \mathrm{~h}$ at room temperature. The suspension was concentrated and dried by the spin-vacuum method. The digested peptide sample was resuspended in $0.1 \%$ trifluoroacetic acid and separated by microbore high-performance liquid chromatography (HPLC) on a Vydac C18 column $(5 \mu \mathrm{m}, 2.1 \times 250 \mathrm{~mm}$; Vydac, Hesperia, CA, USA) using an increasing concentration gradient of

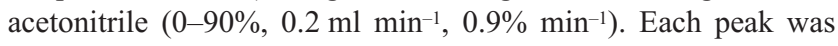
analysed by the sequencer.

\section{Immunohistochemistry}

Surgical specimens of gliomas and medulloblastomas were embedded in OCT compound (Tissue Tek, Miles, IN, USA) and immediately frozen. Immunohistochemical analysis was performed according to the previously described method (Moriuchi et al, 1993). In brief, specimens were fixed with acetone, blocked with gout normal serum, and incubated with primary Abs, such as ONS-M21 MAb, anti-Mac-1 Ab (PharMingen, SanDiego, CA, USA), or anti-glial fibrillary acid protein (GFAP) Ab (Dakopatts). Then, biotinylated goat antimouse or anti-rabbit IgG (Dakopatts) was added as secondary Ab, the samples were washed with PBS, incubated with streptavidin-biotin-peroxidase complex, and immunocomplexes were revealed by the peroxidase reaction using $0.06 \%$ diaminobenzidine with $0.01 \%$ hydrogen peroxidase in $50 \mathrm{~mm}$ Tris- $\mathrm{HCl}$ buffer ( $\mathrm{pH} 7.0)$.

\section{Isolation of total RNA and reverse transcription}

Surgical specimens were treated with Isogen (Nippongene, Tokyo, Japan) and the total RNA was extracted according to the protocol provided by the manufacturer. Total RNA $(10 \mu \mathrm{g})$ was converted to cDNA using oligo-dT primer $\mathrm{pd}(\mathrm{T})^{12-18}(0.5 \mu \mathrm{g}$, Invitrogene, San Diego, CA, USA) as a primer and avian myeloblastosis virus (AMV) reverse transcriptase (28 units, Seikagaku Kogyo, Tokyo, Japan) in $30 \mu \mathrm{l}$ of reverse transcription buffer containing $50 \mathrm{~mm}$ Tris- $\mathrm{HCl}$ ( $\mathrm{pH} 8.3$ ), $100 \mathrm{~mm}$ potassium chloride, $10 \mathrm{~mm}$ magnesium chloride, and $600 \mu \mathrm{M}$ of each dNTP (dATP, dCTP, dGTP and dTTP, Perkin Elmer Cetus, Norwalk, CT, USA), 10 mM dithiothreitol and 10 units of ribonuclease inhibitor (Takara, Kyoto, Japan). The reaction mixture was incubated at $42^{\circ} \mathrm{C}$ for $50 \mathrm{~min}$, heated at $70^{\circ} \mathrm{C}$ for $10 \mathrm{~min}$, chilled on ice and then stored at $-20^{\circ} \mathrm{C}$.

\section{Polymerase chain reaction of cDNA}

On the basis of published sequences (Takada et al, 1991; Tsuji et al, 1991), we prepared pairs of oligonucleotide primers corresponding to sequences of the integrin $\alpha 3$ gene and the housekeeping gene glyceraldehyde-3-phosphate dehydrogenase (GAPDH) as a control. The following gene-specific oligo-nucleotide primers were used: integrin $\alpha 3$ (2154-2173) sense primer 5'-GCCAAGCTAATGAGACCATC-3', antisense primer (2742-2761) 5' -TCAGCACGAGTGCTCGAGACTTG-3', GAPDH (211-231) sense primer 5'-CCCATCACCATCTTCCAGGAG-3', antisense primer (475-495) GTTGTCATGGATGACCTTGGC-3'. The amplified products of integrin $\alpha 3$ and GAPDH were 608 and $285 \mathrm{bp}$ respectively.

One-thirtieth of the RT reaction mixture was used as a source of cDNA. Each polymerase chain reaction (PCR) $(100 \mu \mathrm{l})$ contained $40 \mathrm{pmol}$ of each primer, 2.5 units of Taq polymerase (Amplitaq Gold, Perkin Elmer Cetus), $160 \mu \mathrm{mol} / \mathrm{l}^{-1}$ of each dNTP, $10 \mu \mathrm{l}$ of 
$1 \times$ PCR buffer, 2 mmol $\mathrm{l}^{-1}$ magnesium chloride and cDNA. The reaction was performed in a PCR thermal cycler (Perkin Elmer Cetus). After preheating the mixture at $95^{\circ} \mathrm{C}$ for $9 \mathrm{~min}$, the material for PCR was denatured at $94^{\circ} \mathrm{C}$ for $1 \mathrm{~min}$, annealed at $55^{\circ} \mathrm{C}$ for $1 \mathrm{~min}$ and extended at $72^{\circ} \mathrm{C}$ for $2 \mathrm{~min}$. Typically, 25-40 cycles of amplification were performed. PCR products were size fractionated by gel electrophoresis through $2 \%$ agarose. The density of the separated bands was evaluated using Image Quant (Molecular Dynamics).

\section{RESULTS}

\section{Molecular weight of the ONS-M21 antigen}

In order to determine the molecular weight of the ONS M-21 antigen, we performed immunoprecipitation of ${ }^{35} \mathrm{~S}$-labelled cell extracts of ONS-76 with ONS-M21 MAb. Autoradiography of the sample revealed a $140-\mathrm{kDa}$ band, which was not detected in the negative control lane (Figure 1, lanes 2 and 3). Other weak bands were seen in both lanes. We therefore verified that ONS-M21 $\mathrm{MAb}$ recognizes the $140-\mathrm{kDa}$ protein.

\section{Separation of eluted fractions from the affinity column}

Portions of the eluted fractions from the ONS-M21 mAb-fixed affinity column were blotted onto a nitrocellulose membrane and analysed by the dot-blot ECL system (Amersham). The absorbency of the blots was measured and fractions 10-16 were found to be positive (Figure 2A). A part of the collected sample was separated by SDS-PAGE and stained with silver. One major band migrating with a molecular weight of $140 \mathrm{kDa}$ and one minor band of about $38 \mathrm{kDa}$ were detected (Figure $2 \mathrm{~B}$ ).

\section{Amino acid sequence analysis reveals ONS-M21 antigen to be integrin $\alpha 3$}

About $10 \%$ of the purified sample was concentrated and separated by SDS-PAGE. The main band $(140 \mathrm{kDa})$ was then cut out and the

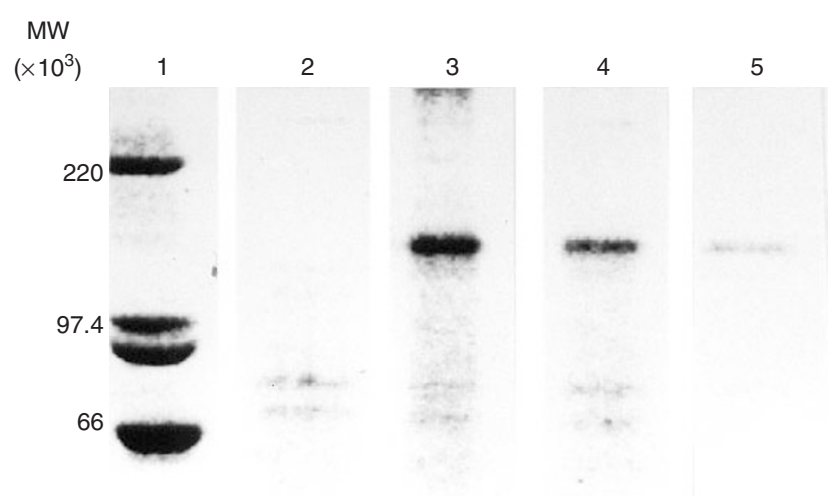

Figure 1 Molecular weight of the ONS-M21 MAb-recognized antigen. Whole-cell extracts of ONS-76 that were labelled with [ ${ }^{35}$ S]methionine were immunoprecipitated with ONS-M21 MAb or P1B5 Ab or control mouse IgG. The precipitates were then analysed using $6 \%$ SDS-polyacrylamide gels. Lane 1, molecular weight standards; molecular weights are indicated in kDa. Lane 2, ONS-76 extract incubated with control lgG. Lane 3, ONS-76 extract incubated with ONS-M21 MAb. Lane 4, ONS-76 extract incubated with P1B5 $\mathrm{Ab}$. Lane 5, ONS-76 extract incubated with ONS-M21 MAb following immunoprecipitation with P1B5 Ab amino acid sequence was analysed. Nineteen of the 20 amino acids from the amino terminus were identified (Figure 3). A homology search revealed that the 18 -amino-acid sequence was identical to the amino-terminal sequence of human integrin $\alpha 3$ (Takada et al, 1991; Tsuji et al, 1991).

The cyanogen bromide-treated sample was applied to a HPLC column to separate the digested peptides. Although many peaks were detected, five peptides were chosen for amino acid sequence analysis. All of the identical sequences showed complete matches with the internal sequence of integrin $\alpha 3$ (Figure 3; Takada et al, 1991; Tsuji et al, 1991).

\section{ONS-M21 MAb recognizes the same antigen as the commercially available anti-integrin $\alpha 3 \mathbf{A b}$}

We performed immunoprecipitation with ONS-M21 MAb and commercially available anti-integrin $\alpha 3$ Ab, P1B5 Ab, from ${ }^{35} \mathrm{~S}$ labelled cell extracts of ONS-76. Both Abs recognized a protein with a molecular weight of $140 \mathrm{kDa}$ (Figure 1, lanes 3 and 4). The supernatant of the cell extract, which had been already immunoprecipitated with P1B5 Ab, was reimmunoprecipitated with ONSM21 MAb. The $140-\mathrm{kDa}$ band in lane 5 of Figure 1 was extremely faint compared with that of lane 3. This suggests that P1B5 Ab and ONS-M21 MAb interact with a common antigen.

\section{Protein expression and mRNA transcription of the ONS-M21 antigen gene in surgical specimens of gliomas and medulloblastomas}

Surgical specimens of gliomas and medulloblastomas were classified according to the histological classification of tumours of the central nervous system (Daumas-Duport et al, 1988; Kleihues and Burger, 1993). In tumour specimens of grade II gliomas, scattered staining with ONS-M21 MAb was immunohistochemically observed (Figure 4A). The number of positive cells increased in grade III gliomas (data not shown). Many positive cells were detected in glioblastoma (grade IV) (Figure 4B). In surgical specimens, cells recognized by ONS-M21 MAb were not positively stained with anti-Mac-1 Ab and anti-GFAP Ab (Figure 4D and E). All things considered, these cells would appear not to be microglial cells or reactive astrocytes, but rather tumour cells.

As surgical specimens do not always suffice to purify a sufficient amount of RNA, RT-PCR had to be used instead of Northern blotting analysis. To determine the appropriate number of cycles for quantitative evaluation of the amount of cDNA, the correlation between the PCR cycle number and the amount of RT-PCR product was examined. Through preliminary evaluation, we chose 25 cycles of PCR for GAPDH cDNA and 35 cycles for integrin $\alpha 3$ cDNA. These RT-PCR products were mixed at a GAPDH to integrin $\alpha 3$ volume ratio of 0.5 , and they were separated using $2 \%$ agarose gel electrophoresis (Figure 5A). Integrin $\alpha 3$ mRNA transcription expressed as a ratio of that of the housekeeping gene GAPDH is shown in Figure 5. There was a tendency for integrin $\alpha 3$ mRNA transcription to increase with the glioma grade of malignancy (Figure 5B).

\section{DISCusSION}

In this report, we have demonstrated that the target molecule of monoclonal antibody ONS-M21 is human integrin $\alpha 3$. The molecular weight of this antigen was previously reported to be $90-\mathrm{kDa}$ 
A

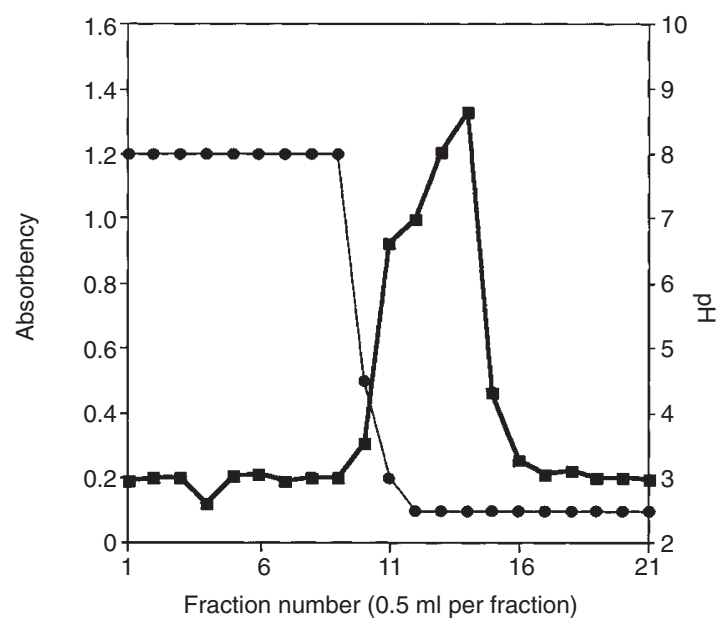

B

9.74

kDa

1 2

66

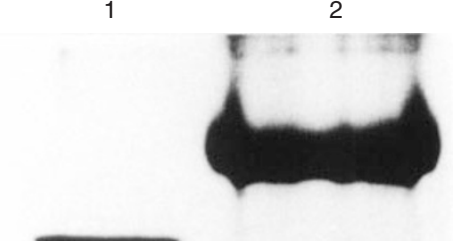

45
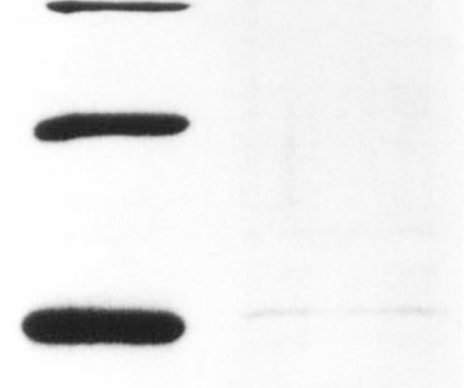
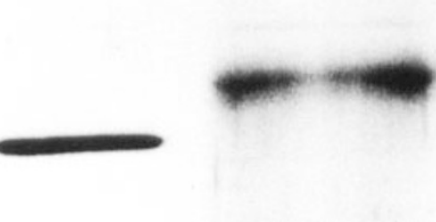

Figure 2 Purification of ONS-M21 antigen. (A) The antigen recognized by ONS-M21 MAb from ONS-76 cell extracts was purified using ONS-M21 MAb-fixed affinity chromatography. The bound protein was eluted with acid buffer and the antigen concentration of each fraction was determined by immunoblotting using an ECL system. Squares represent the absorbency of dot blots. Circles represent the pH of the eluted samples. (B) SDS-PAGE of the ONS-M21 antigen purified using ONS-M21 MAb-affinity column chromatography. Positive samples of ECL dot blots were mixed together, condensed, separated by $7.5 \%$ SDSPAGE and stained with silver. Lane 1, molecular weight standards; molecular weights are in kDa. Lane 2, eluted sample

A

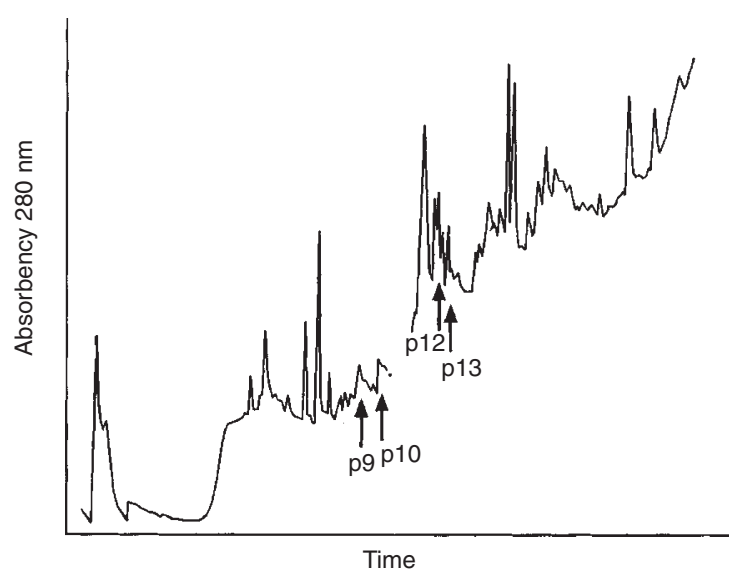

B

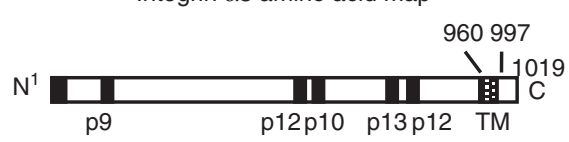

$\mathrm{N}$-terminal

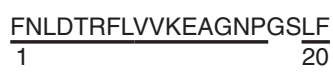

p9

MNITVKNDPGHHIIEDM

p12, p10

MDNLRDKLRPIIISMNYSLPLRM

p13 MVNHRLQSFFGGTVM

p12 MKTVEDVGSPLKYEFQVGPM

754

771

Figure 3 Amino acid sequence of ONS-M21 antigen. (A) CNBr-digested peptide map of the protein eluted from the ONS-M21 affinity column. The bound protein was treated with $70 \%$ formic acid containing $2 \mathrm{mg}$ of CNBr. The peptides were dissolved in $0.1 \%$ trifluoroacetic acid and analysed by HPLC. The amino acid sequences of p9,10,12 and 13 were obtained. (B) The sequences of the amino-terminal and internal domains were obtained from the purified antigen. The sequences were aligned with residues 1-20, 75-89, 527-539, 541-547, 735-747 and 754-771 of the deduced amino acid sequence of integrin $\alpha 3$. TM, transmembrane region of integrin $\alpha 3 ; \mathrm{N}$, amino-terminal; C, carboxy-terminal

protein (Moriuchi et al, 1993), which is at least $50 \mathrm{kDa}$ smaller than the integrin $\alpha 3$ detected in this report. This discrepancy turns out to be due to an error of the molecular weight marker in the previous report. Hence, the exact molecular weight should now be considered to be $140 \mathrm{kDa}$, as described in this report (Figure 1). Two molecular species of protein were adsorbed to the ONS-M21 MAb-binding column (Figure 2). Sequence analysis revealed the protein of the major band to be integrin $\alpha 3$. This analysis also demonstrated that the other 38-kDa protein had homology with the P32 subunit of premRNA splicing factor SF2 (Honore et al, 1993). However, no 


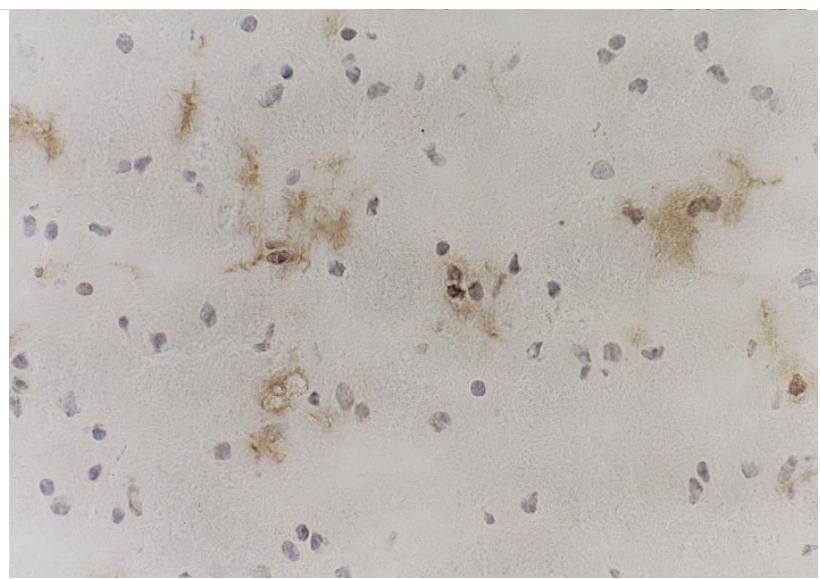

C

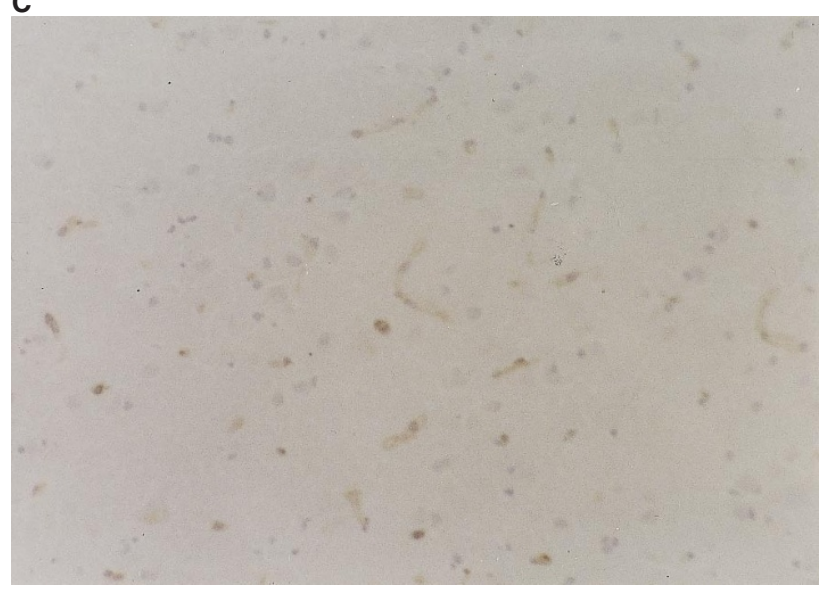

E

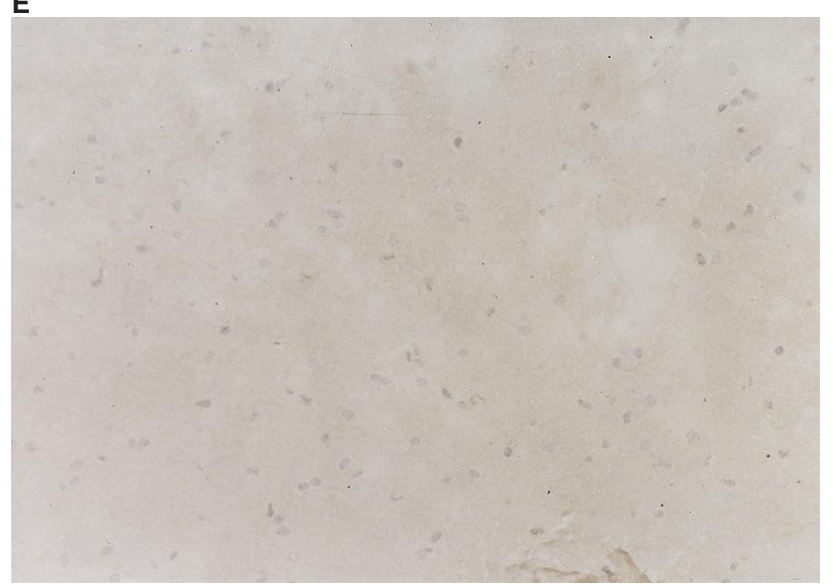

positive band other than the $140-\mathrm{kDa}$ band was detected by immunoprecipitation. We also purified this antigen from the subcutaneously transplanted ONS-76 cells of nude mice. SDS-PAGE and silver staining revealed the presence of the $140-\mathrm{kDa}$ band but no $38-\mathrm{kDa}$ band was detected (data not shown). Commercially available P1B5 $\mathrm{Ab}$, which recognized integrin $\alpha 3$, could precipitate the same molecular weight protein as ONS-M21 MAb (Figure 1). In the competitive immunoprecipitation experiment, prior treatment of the samples with P1B5 Ab resulted in failure of ONS-M21 MAb to precipitate the antigen, suggesting that P1B5 Ab and ONS-M21 MAb compete

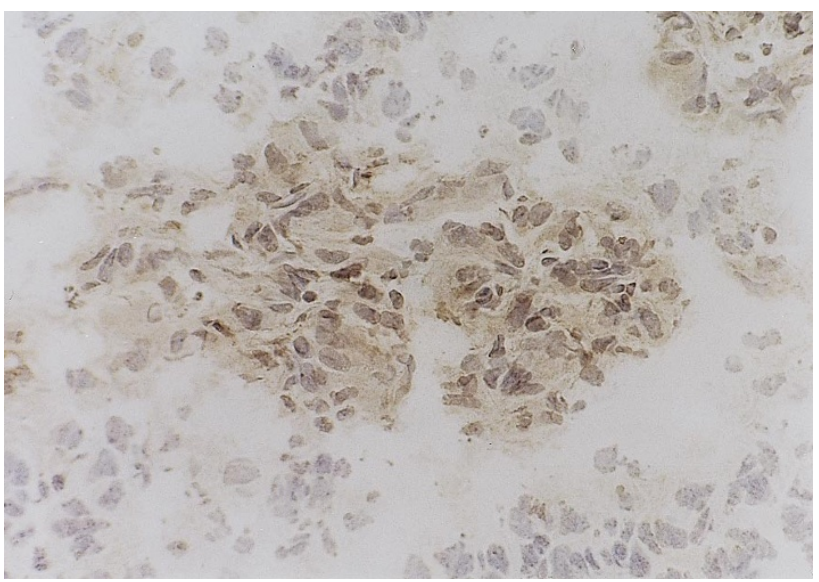

D

Figure 4 Immunohistochemical staining of glioma specimens. (A) Grade II glioma with ONS-M21 MAb. (B) Grade IV glioma with ONS-M21 MAb. (C, D and $\mathbf{E})$ are the same section from adjacent slices of grade II glioma. (C) With ONS-M21 mAb. (D) With anti-Mac-1 Ab. (E) With anti-GFAP Ab. (A and B) Original magnification $\times 200$. (C, D and E) Original magnification $\times 100$

for the same antigen (Figure 1). These results, taken together, suggest that the ONS-M21 antigen is identical to integrin $\alpha 3$.

According to the literature, integrin $\alpha 3$ is not distributed on oligodendrocytes, ependymal cells, neurons or microglias (Paulus et al, 1993). Our experiment showed that cells recognized by ONS-M21 MAb are neither microglias nor reactive astrocytes (Figure 4). This also supports the idea that ONS-M21 MAb reacts with integrin $\alpha 3$ expressed on glioma cells.

Furthermore, to investigate for mutations of this protein expressed in glioma cells, we examined the cDNA sequence of the 
A

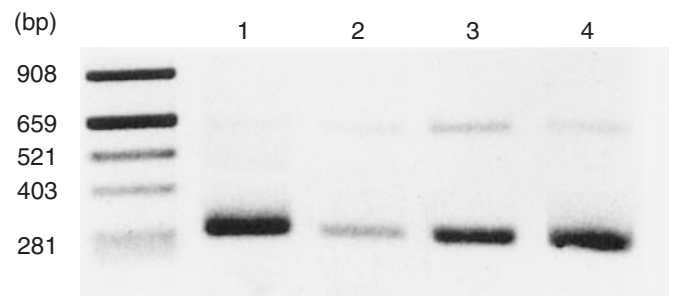

B

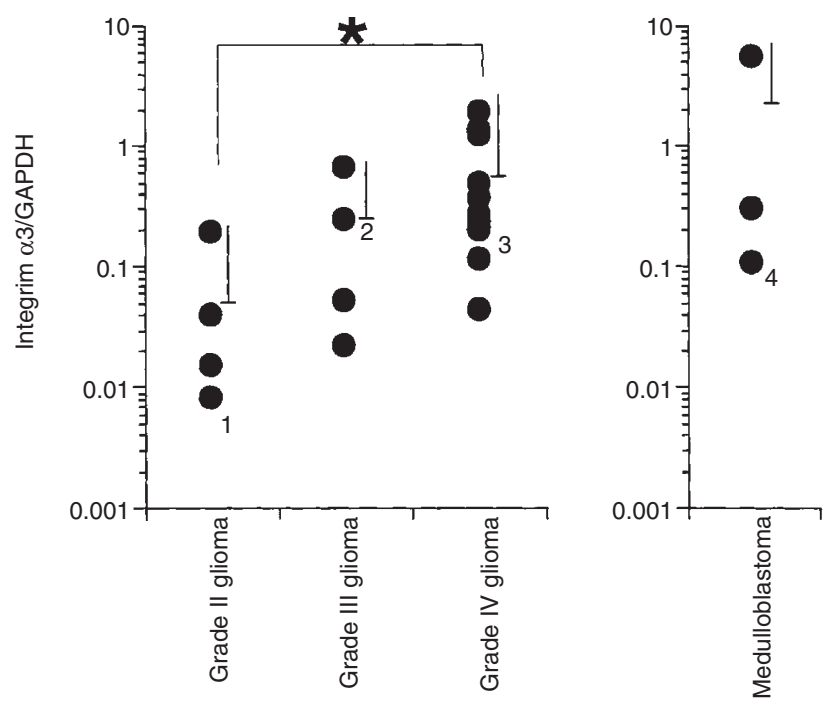

Figure 5 Correlation between the glioma grade of malignancy and the mRNA transcription level of integrin $\alpha 3$. (A) Electrophoretic pattern of RTPCR products from surgical specimens. Lane 1, surgical specimen of glioma grade II. Lane 2, surgical specimen of glioma grade III. Lane 3, surgical specimen of glioma grade IV. Lane 4, surgical specimen of medulloblastoma. Upper band $(608 \mathrm{bp})$ and lower band $(285 \mathrm{bp})$ indicate the amplified PCR products of integrin $\alpha 3$ and GAPDH respectively. (B) Transcription of integrin $\alpha 3$ mRNA in surgical specimens of gliomas and medulloblastomas. RT-PCR products were separated by electrophoresis and their absorbency was measured using a densitometer. Integrin $\alpha 3$ mRNA expression was evaluated as the ratio of absorbency of the amplified band of integrin $\alpha 3$ to that of GAPDH. Numbers in the figure correspond to the lane numbers in (A). Horizontal bars represent the mean value of the ratio of the absorbencies. Vertical bars indicate standard errors. There is a statistical difference between grade II glioma and grade IV glioma. Statistical evaluation by Student's $t$-test. ${ }^{\star} P<0.01$

coding region of integrin $\alpha 3$ in five glioma cell lines. No common cDNA mutations causing amino acid replacements or deletions were detected among these cell lines (data not shown). These findings suggest that ONS-M21 MAb recognizes the normal form of integrin $\alpha 3$ expressed in these glioma cell lines.

Many monoclonal antibodies against gliomas, prepared by immunizing mice with glioma cells, have been reported. Some of those antibodies have been analysed with regard to their target molecules (Schold et al, 1993; Okada et al, 1994; Romejin et al, 1994). Mouse MAbs against gliomas have also been applied in experimental models. Some Abs were expected to have an antitumour effect by themselves (Dastider and Sharma, 1995), and others were used in combination with a radioisotope (Williams et al, 1990) or chemotherapeutic agent (Schrappe et al, 1992). Furthermore, some MAbs have also been applied to clinical diagnosis and therapies, even though these Abs were derived from mice (Daghighian et al, 1993; Schold et al, 1993; Faillot et al, 1996). Human Ab is preferred for clinical applications because mouse $\mathrm{Ab}$ can be more immunogenic than human Ab. Although human MAbs against gliomas have been produced, their target molecules have not been reported (Dan et al, 1992, 1995). Recombinant humanized ONS-M21 Ab has already been successfully produced (Ohtomo et al, 1995), and therefore hONS-M21 Ab is the only $\mathrm{Ab}$ against gliomas whose target molecule has been identified. The expression of integrin $\alpha 3$ in the normal brain has been reported to be very low or even undetectable (Fradet et al, 1984; McGeer et al, 1990; Paulus et al, 1993), and ONS-M21 $\mathrm{MAb}$ is not reactive to either fetal or adult brain tissues (Moriuchi et al, 1993). A significant amount of ONS-M21 MAb attached to the cell surface was rapidly internalized into the cytoplasm, and the A-chain of ricin-conjugated ONS-M21 MAb displayed glioma specific cell toxicity in vitro (Shimizu et al, 1998). ${ }^{125}$ I-labelled hONS-M21 Ab was found to accumulate in the glioma of nude rat brains $24 \mathrm{~h}$ after intravenous administration (data not shown). In this way, hONS-M21 Ab is attractive for clinical applications such as for pathological diagnosis or glioma-specific targeting.

Integrin $\alpha 3$ is one of the adherent molecules that binds to collagen, laminin and fibronectin (Elices et al, 1991; Takeda et al, 1991), although it is still controversial as to whether integrin $\alpha 3$ induces cell-cell adhesion (Shiramarao et al, 1993; Weitzmen et al, 1995). The expression of integrin $\alpha 3$ in fibroblasts increases following oncogenic transformation (Tsuji et al, 1991). In malignant tumours, poorly differentiated hepatocellular carcinomas show down-regulation of integrin $\alpha 3$ (Jaskiewicz and Chasen, 1995), an abundant expression of which is related to the mode of gastric and colorectal cancer invasion (Boku et al, 1995). Furthermore, transfection with cDNA coding for integrin $\alpha 3$ reduced the tumorgenicity of rhabdomyosarcoma cells (Weitzman et al, 1996). Thus, the expression of integrin $\alpha 3$ is different depending on the type of cancer and the level of malignancy. Although immunohistochemical analysis of integrin $\alpha 3$ in gliomas has been demonstrated (Paulus et al, 1993), no quantitative evaluation has been reported. In the present study, we quantified integrin $\alpha 3$ mRNA by an RT-PCR method using GAPDH genes as an internal control, in accordance with previous reports (Suzuki et al, 1995; Zhao et al, 1995). The results showed that integrin $\alpha 3$ was transcribed in all gliomas and medulloblastomas and that the amount of integrin $\alpha 3$ increased with the grade of the malignancy. The results of this study suggest that integrin $\alpha 3$ may play some role during the development of malignancy in glioma, such as invasion or infiltration of the surrounding brain. It would be interesting to investigate the pathophysiological mechanisms of the ONS-M21 antigen, which we have shown in this report to be integrin $\alpha 3$.

\section{ACKNOWLEDGEMENT}

This work was supported by a grant-in-aid for scientific research (08457363) from the Ministry of Education, Science, Sports and Culture of Japan.

\section{REFERENCES}

Boku N, Yoshida S, Ohtsu A, Fujii T, Koba I, Oda Y, Ryu M, Matsumoto T, Hasebe T, Hosokawa K, Yama T, Saito D, Moriya N and Abe K (1995) Expression of integrin $\alpha 3$ in gastric and colorectal cancers: Its relation to wall construction and mode of invasion. Jpn J Cancer Res 86: 934-940 
Daghighian F, Pentlow KS, Larson SM, Graham MC, DiResta GR, Yeh SDJ, Macapinlac H, Finn RD, Arbit E and Cheung NKV (1993) Development of a method to measure kinetics of radiolabelled monoclonal antibody in human tumor with applications to microdosimetry: Positron emission tomography studies of iodine-124 labeled 3F8 monoclonal antibody in glioma. Eur J Nucl Med 20: 402-409

Dan MD, Schlachta CM, Guy J, McKenzie RG, Dorsscheid DR, Sandor VA, Villemure JG and Price GB (1992) Human antiglioma monoclonal antibodies from patients with astrocytic tumors. J Neurosurg 76: 660-669

Dan MD, Earley EM, Griffin MC, Maiti PK, Prashar AK, Yuan XY, Friesen AD and Kaplan HA (1995) Human monoclonal antibody BT32/A6 and a cell cycleindependent glioma-associated surface antigen. J Neurosurg 82: 475-480

Dastidar SG and Sharma SK (1995) Monoclonal antibody against human glioblastoma multiforme (U-87MG) immunoprecipitates a protein of molecular weight $38 \mathrm{kDa}$ and inhibits tumor growth in nude mice. J Neuroimmunol 56: 91-98

Daumas-Duport C, Scheithauer B, O'Fallon J and Kelly P (1988) Grading of astrocytoma. A simple and reproducible method. Cancer 62: 2152-2165

Elices MJ, Urry LA and Hemler ME (1991) Receptor function for the integrin VLA3: Fibronectin, collagen, and laminin binding are differentially influenced by ARG-GLY-ASP peptide and by divalent cations. J Cell Biol 112: 168-181

Evans AE, Jenkin RD, Sposo R, Ortega JA, Wilson CB, Wara W, Ertel IJ, Kramer S, Chang CH, Leikin SL and Hammond GD (1990) The treatment of medulloblastoma. Results of a prospective randomized trial of radiation therapy with and without $\mathrm{CCNU}$, vincristine, and predonisone. J Neurosurg $\mathbf{7 2}$ : $572-582$

Faillot T, Magdelent H, Mady E, Stasiecki P, Fohanno D, Gropp P, Poisson M and Delattre JY (1996) A phase I study of an anti-epidermal growth factor receptor monoclonal antibody for the treatment of malignant gliomas. Neurosurgery 39 478-483

Fradet Y, Cardo CC, Thomson T, Daly ME, Whitmore WF Jr, Lloyd KO, Melamed MR and Old LJ (1984) Cell surface antigen of human bladder cancer defined by mouse monoclonal antibody. Proc Natl Acad Sci USA 81: 224-228

Honore B, Madsen P, Rasmussen HH, Vandekerckhove J, Celis JE and Leffers H (1993) Cloning and expression of a cDNA covering the complete coding region of the P32 subunit of human pre-mRNA splicing factor SF2. Gene $\mathbf{1 3 4}$ : $283-287$

Jaskiewicz K and Chasen MR (1995) Differential expression of transforming growth factor alpha, adhesion molecules and integrin in primary, metastatic liver tumors and in cirrhosis. Anticancer Res 15: 559-562

Kleihues P and Burger PC (1993) Histological Typing of Tumors of the Central Nervous System. Springer: Berlin

McGeer PL, Zhu SG and Dedhar S (1990) Immunostaining of human brain capillaries to antibodies to very late antigens. J Neuroimmunol 26: 213-218

Moriuchi S, Shimizu K, Miyao Y and Hayakawa T (1993) Characterization of a new mouse monoclonal antibody (ONS-M21) reactive with both medulloblastomas and gliomas. Br J Cancer 68: 831-837

Ohtomo T, Tsuchiya M, Sayo K, Shimizu K, Moriuchi S, Miyao Y, Akimoto T, Akamatsu K, Hayakawa T and Ohsugi Y (1995) Humanization of mouse ONSM21 antibody with the aid of hybrid variable regions. Mol Immunol 32: 406-407
Okada H, Yoshida J, Seo H, Wakabayashi T, Sugita K and Hagiwara M (1994) Anti(glioma surface antigen) monoclonal antibody G-22 recognizes overexpressed CD44 in glioma cells. Cancer Immunol Immunother 39: 313-317

Paulus W, Baur I, Schuppan D and Roggendorf W (1993) Characterization of integrin receptors in normal and neoplastic human brain. Am J Pathol 143: 154-163

Romeijin P, Lenthall R, Stavrou D, Melcher D, Ladyman H and Ritter MA (1994) Identification of glioma-associated antigen MUC 2-63 as CD44. Br J Cancer 70: 799-803

Schold SC, Zalutsky MR, Coleman RE, Glantz MJ, Friedman AH, Jaszczak RJ, Bigner SH and Bigner DD (1993) Distribution and dosimetry of I-123-labeled monoclonal antibody $81 \mathrm{C} 6$ in patients with anaplastic glioma. Invest Radiol $\mathbf{2 8}$ : $488-496$

Schrappe M, Bumol TF, Apelgren LD, Briggs SL, Koppel GA, Markowittz DD, Mueller BM and Reisfeld RA (1992) Long-term growth suppression of human glioma xenografts by chemoimmunoconjugates of 4-desacetylvinblastine3-carboxyhydrazide and monoclonal antibody 9.2.27. Cancer Res $\mathbf{5 2}$ : 3838-3844

Shimizu K, Park KC, Tamura K, Kishima H, Kawata H, Yoshimura Y, Sekimori Y, Miyao Y and Hayakawa T (1998) Internalization with high targeting potential of mouse monoclonal antibody ONS-M21 recognizing human malignant glioma antigen. Cancer Lett 27: 171-176

Shiramarao P, Steffner P and Gehlsen KR (1993) Biochemical evidence for a homophilic interaction of the $\alpha 3 \beta 1$ integrin. J Biol Chem 268: 22036-22041

Suzuki H, Shibata H, Murakami M, Sato A, Naito M, Ichihara A, Matsumoto A, Tsujimoto G, Hiarasawa A, Horie K and Saruta T (1995) Modulation of angiotensin II type 1 receptor mRNA expression in human blood cells: Comparison of platelets and mononuclear leucocytes. Endo J 42: 15-22

Takada Y, Murphy E, Pil P, Chen C, Ginsberg MH and Hemler ME (1991) Molecular cloning and expression of the cDNA for $\alpha 3$ subunit of human $\alpha 3 \beta 1$ (VLA-3), an integrin receptor for fibronectin, laminin, and collagen. J Cell Biol 115: $257-266$

Tamura K, Shimizu K, Yamada M, Okamoto Y, Matsui Y, Park KC, Mabuchi E, Moriuchi S and Mogami H (1989) Expression of major histocompatibility complex on human medulloblastoma cells with neuronal differentiation. Cancer Res 49: 5380-5384

Tsuji T, Hakomori SI and Osawa T (1991) Identification of human galactoprotein b3, an oncogenic transformation-induced membrane glycoprotein, as VLA$3 \alpha$ subunit: the primary structure of human integrin $\alpha 3$. J Biochem 109: $659-665$

Weitzman JB, Chen A and Hemler ME (1995) Investigation of the role of integrins in cell-cell adhesion. J Cell Sci 108: 3635-3644

Weitzman JB, Hemler ME and Brodt P (1996) Reduction of tumorigenicity by $\alpha 3$ integrin in a rhabdomyosarcoma cell line. Cell Adh Comm 4: 41-52

Williams JA, Wessels BW, Edwards JA, Kopher KA, Wanek PW, Whram MD, Order SE and Klein JL (1990) Targeting and therapy of human glioma xenografts in vivo utilizing radiolabeled antibodies. Cancer Res 50: 974-979

Zhao J, Nobuhito A and Nishimoto SK (1995) Quantitation of matrix Gla protein mRNA by competitive polymerase chain reaction using glyceraldehyde-3phosphate dehydrogenase as an internal control. Gene 155: 159-165 